\title{
The role of preservation on the quantification of morphology and patterns of disparity within Paleozoic echinoderms
}

\author{
Bradley Deline, ${ }^{1}$ and James R. Thomka ${ }^{2}$ \\ ${ }^{1}$ Department of Geosciences, University of West Georgia, Carrollton, GA 30118, USA 〈bdeline@ westga.edu \\ ${ }^{2}$ Department of Geosciences, University of Akron, Akron, OH 44325, USA 〈jthomka@uakron.edu〉
}

\begin{abstract}
The loss of information resulting from taphonomic degradation could represent a significant bias in the study of morphological diversity. This potential bias is even more concerning given the uneven effect of taphonomy across taxonomic groups, depositional facies, and stratigraphic successions and in response to secular changes through the Phanerozoic. The effect of taphonomic degradation is examined using character-based morphological data sets describing disparity in Paleozoic crinoids and blastozoans. Characters were sequentially excluded from the analyses following progressive taphonomic loss to determine how morphologic metrics, such as the relative distribution of taxa in morphospace and partial disparity, changed with increasing taphonomic alteration. Blastozoans showed very little change in these metrics with decreasing preservational quality, which is a result of characters that create distance in morphospace being recognizable in isolated plates. The opposite result is present in crinoids as the characters that are important in structuring the morphospace require intact modules (i.e., the calyx) to accurately assess. Temporal and stratigraphic trends produced encouraging results in that patterns could be largely recovered even with exaggerated taphonomic biases. However, certain parts of a stratigraphic sequence should be avoided and morphological outliers could potentially play a larger role through time, though both of these biases can be easily identified and avoided. The methods presented in this study provide a way to assess potential taphonomic biases in character-based studies of morphological diversity.
\end{abstract}

\section{Introduction}

There are multiple methodologies that can be used to explore macroevolutionary trends. The most common metrics are taxonomic diversity and phylogenetic analyses, both of which are fundamental within paleontology. However, each focuses on a fairly narrow subset of evolutionary processes: phylogenetic analysis based on parsimony attempts to reconstruct evolutionary relationships, whereas taxonomic diversity tracks the changes in the number of biologically distinctive units, which is a function of the relative rates of speciation and extinction. The amount of morphological change within a lineage or during a speciation event, as well as the type of extinction event (selective or random in relation to particular morphotypes), is not prominently captured using these methods. Morphological diversity-disparity-is a much more encompassing metric in the exploration of large-scale macroevolutionary patterns, and consequently, its interpretation can be more problematic and varied (Foote, 1997a; Lloyd, 2016). In addition, disparity requires the quantification of morphology, which can be laborious and time consuming such that disparity is relatively understudied with regard to both pattern and potential biases. Ideally, multiple methods (diversity, disparity, and phylogenetic reconstruction) would be used in concert (e.g., Gorscak and O'Connor, 2016) to gain an even more expansive view of evolutionary histories. However, this further expands the labor, data, and exploration of biases required for reliable results, and reliable phylogenies are elusive for many groups of fossil organisms, especially at higher taxonomic levels.

The characterization of morphology can be accomplished using multiple techniques, including the use of morphometrics (e.g., landmarks or outlines analysis) in two dimensions (Crônier et al., 1998; Crampton, 2007; Webber and Hunda, 2007) or three dimensions (Eble, 2000; Goswami et al., 2011), discrete characters (Briggs et al., 1992; Wagner, 1997; Wills, 1998; Foote, 1999), and GIS analysis (Sheffield et al., 2012; Wilson et al., 2012; Knauss and Yacobucci, 2014). Each of these methods has its strengths and focus, and in some cases, they have been shown to produce similar morphologic patterns (Villier and Eble, 2004; Hetherington et al., 2015). Studies of the potential biases in detecting morphological diversity are fairly limited, especially with the myriad of available approaches, but the influences of metric (Ciampagio et al., 2001), environmental distribution (Hopkins, 2014), community structure (Deline, 2009), and taxonomic or geographic scale (Butler et al., 2012; Deline et al., 2012) have been investigated. Of particular interest are the effects of variable preservation and taphonomy on the characterization of morphology. This potential bias is especially concerning given that it may result in the loss of taxa, loss of features, loss of entire body regions, and/or alteration of the features that are preserved. Foote (1997b) explored the sensitivity of disparity to taxon sampling, which captures part of the taphonomic bias on estimates of disparity, i.e., differential recovery of organisms. However, how much 
and what part of the animals is recovered may be as important as recovering the animal at all. Few studies have examined taphonomy in regard to disparity (see Webster and Hughes, 1999 for an example), but the loss of soft-tissue characters has been shown to make taxa appear more ancestral in phylogenetic analyses (Sansom and Wills, 2013). This may be especially problematic at higher taxonomic levels owing to greater intrinsic (e.g., intraclade) variability in the taphonomic sensitivity of the organisms or features being studied. One method that may be particularly susceptible to these biases is the use of discrete characters, which is often used to describe large-scale trends in disparity (Briggs et al., 1992; Foote, 1992; Wagner, 1997; Wills, 1998; Ciampaglio, 2004; Deline, 2015; also see reviews by Foote, 1997a; Erwin, 2007; Hughes et al., 2013).

Paleozoic echinoderms represent an ideal group for a case study of potential bias associated with preservation because they contain a wide array of morphological features (Pawson, 2007); their patterns of disparity are well documented (Foote, 1994, 1999; Deline and Ausich, 2011); and they have predictable and empirically tested patterns of taphonomic degradation (e.g., Kidwell and Baumiller, 1990; Greenstein, 1991). In addition, Deline and Ausich (2017) found that the magnitude and order of relative disparity of crinoid groups changed with varying emphasis on different body regions, which is also likely to occur as skeletal regions are differentially affected by taphonomic alteration. To explore these potential biases, we examined how the quantification of morphology in Paleozoic stalked echinoderms is influenced by variations in preservation and how those variations could potentially alter observed morphological trends in different taphofacies or through time.

\section{Echinoderm taphonomy}

The echinoderm endoskeleton consists of a multitude of individual ossicles, varying in number from dozens in irregular echinoids (e.g., Smith, 1984) to hundreds of thousands in crinoids (e.g., Macurda and Meyer, 1983; Meyer and Meyer, 1986). These ossicles are bound together primarily by unmineralized connective tissues, including ligaments and, in some taxa, muscles. This intricate, soft tissue-bound morphology makes echinoderms among the most taphonomically volatile of well-skeletonized macroinvertebrates: in the absence of burial, echinoderms will undergo skeletal disarticulation into isolated ossicles as conspicuously evidenced by the abundance of Paleozoic carbonates composed entirely or predominantly of isolated pelmatozoan columnals (Lowenstam, 1957; Ausich, 1997). Field and laboratory studies of extant echinoderms have repeatedly confirmed the rapid rate of postmortem disarticulation under normal environmental conditions (e.g., Blyth Cain, 1968; Meyer, 1971; Schäfer, 1972; Liddell, 1975; Lewis, 1986; Meyer and Meyer, 1986; Allison, 1990; Kidwell and Baumiller, 1990; Greenstein, 1991, 1993; Baumiller et al., 1995; Greenstein et al., 1995; Gorzelak and Salamon, 2013, among many others). Detailed taphonomic evaluation of Paleozoic faunas supports an equally rapid rate of disarticulation for extinct echinoderm groups if not removed from the taphonomically active zone (e.g., Meyer, 1990; Sumrall, 2000; Dornbos and Bottjer, 2001; Zamora et al., 2013b; Martin et al., 2015; Thomka et al., 2016).
Despite the rapid rate of echinoderm disarticulation, the specific taphonomic pathways recorded by echinoderm skeletal preservation provide accurate and precise information about paleoenvironmental processes and parameters (e.g., Brett and Baird, 1986, 1993; Speyer and Brett, 1991; Thomka et al., 2012), biotic influences and interactions (e.g., Maples and Archer, 1989; Nebelsick et al., 1997), constructional morphology (e.g., Ausich and Baumiller, 1993, 1998; Baumiller and Hagdorn, 1995; Baumiller, 2003), and major biases in the fossil record (e.g., Kier, 1977; Greenstein, 1991, 1992; Donovan, 2001). This interpretive value stems largely from the nonrandomness of disarticulation patterns, which directly reflect the distribution and relative lability of connective tissues (for example, muscular vs. ligamentary articulations in different parts of crinoids) and the presence of significant structural features (e.g., imbricated vs. tessellating plates and presence vs. absence of internal support 'pillars' in different groups of echinoids). Hence, it is well established that different echinoderm skeletal modules and morphotypes respond differently to physical, chemical, and biological processes in operation following death of the individual (Donovan, 1991; Brett et al., 1997; Ausich, 2001).

The difference in the relative propensity for echinoderm skeletal modules to undergo total disarticulation was emphasized by Brett et al. (1997), who identified three 'types' of echinoderm. Type 1 echinoderms are characterized by a general lack of rigid skeletal modules; consequently, these are most susceptible to rapid and total disarticulation. These taxa, which include most asterozoans, edrioasteroids, homalozoans, and loosely plated eocrinoids, are generally only preserved as isolated ossicles, reflecting only minor exposure prior to final burial in many instances, or as complete, articulated individuals, generally reflecting live burial. Type 2 echinoderms are characterized by variability in the relative durability of skeletal modules, with some portions of the skeleton capable of resisting disarticulation longer than others. As a result, these organisms are typically found in a wider range of states of completeness, reflecting differences in rigidity or volume of connective tissues. Examples include regular echinoids, many crinoids, and most blastozoans. Finally, Type 3 echinoderms are characterized by relatively robust skeletal modules that were capable of resisting total disarticulation for more extended periods of time. As with Type 1 echinoderms, these taxa are generally found in a limited number of taphonomic states; examples include sand dollars, blastoids, and most microcrinoids.

Moreover, within a single 'type' of echinoderm (sensu Brett et al., 1997), taphonomic variability can be produced by differing the exposure time of skeletons prior to final burial. As described in the preceding, Type 1 and Type 3 echinoderms are less affected by this factor than are Type 2 taxa due to the skeletal fragility and skeletal robustness, respectively, of these groups. Nevertheless, the progression from completely articulated individual to partially articulated modules, and eventually to isolated ossicles, can be documented for each echinoderm type-it simply occurs significantly more rapidly in Type 1 echinoderms and over a more extended interval for Type 3 echinoderms. It is important to note that as disarticulation progresses, plating configurations are disrupted and morphology becomes increasingly obscured; hence, features 
that can only be reliably assessed on articulated individuals become impossible to describe with increasing taphonomic alteration.

The comparative framework erected by Brett et al. (1997), and slightly modified by Ausich (2001), serves as a useful tool for assessing taphonomic patterns among echinoderms on multiple temporal scales. Because the record of all three types extends throughout the Phanerozoic (Lefebvre et al., 2013; Zamora et al., 2013a), microstratigraphic to secular taphonomic trends can be recognized on the basis of: (1) the relative proportion of each echinoderm skeletal type, and (2) the specific preservational state with regard to discrete physical characters that are identifiable in any given deposit.

\section{Quantification of morphology}

Data matrices.-Two discrete morphological character matrices were utilized in the current study (Table 1). The first was constructed by Foote (1992) to characterize morphologic trends in blastozoan echinoderms (data set available at: http://geosci. uchicago.edu/ foote/MORPHDAT/BLASTOZOAN_DATA. TXT). The matrix is composed of 56 multistate and binary characters describing features across the entire body with particular emphasis on the ambulacral and feeding structures, thecal morphology, attachment structures, and respiratory features. The data set includes 131 genera encompassing multiple skeletal types (Brett et al., 1997) including Type 1 (eocrinoids), Type 2 (eocrinoids, rhombiferans, paracrinoids, and diploporitans), and Type 3 (coronoids and blastoids) echinoderms. The individual codings were not changed from those of Foote (1992) other than the addition of character contingencies that allowed the distinction between absent and nonapplicable character states.

The second data set is the recently constructed crinoid character suite (Supplemental Data 1) developed by Ausich et al. (2015) and Deline and Ausich (2017). This character suite was built as part of the Assembling the Echinoderm Tree of Life Project (AEToL) and differs from previous data sets (e.g., Foote, 1999) by increasing the overall size of the character suite as well as adding characters that accommodate the unique morphology of the protocrinids (Guensburg and Sprinkle, 2003). In addition, the AEToL data set incorporates characters describing the oral surface according to the Universal Elemental Homology model (Sumrall and Waters, 2012; Kammer et al., 2013). This data set is composed of 178 binary and multistate characters with contingencies describing 198 Ordovician through early Silurian crinoids including cladids, flexibles, camerates, hybocrinids, protocrinids, and disparids (Supplemental Data 2). Unlike the blastozoan character matrix, the crinoids all represent a single skeletal type (Type 2).

Analytical protocols.-Characters were coded following the methods of Deline (2009) as a given character state (including absent), missing (unknown because of preservation), or nonapplicable. Characters or taxa with a large amount of unknown data were excluded from analyses, which reduced the crinoid data set to 163 species and 145 characters.

The character states in the two matrices were then serially recoded to assess changes in taphonomic state. This was done in a crude sense following Brett et al. (1997). Even though taphonomic degradation occurs along a continuous gradient, four distinctive bins (taphonomic grades) were used (see Fig. 1 for an example). Taphonomic Grade A represents rapid burial within hours to days following death, resulting in complete and articulated preservation regardless of the skeletal type of echinoderm. The following grades represent a longer time in the taphonomically active zone from days to weeks (Grade B), weeks to years (Grade C), to more than a year (Grade D). A longer duration of taphonomic alteration results in a greater degree of disarticulation with progressive deterioration from intact skeletons to intact body regions to intact portions of skeletal modules to individual ossicles. In addition, the amount of abrasion on individual elements was modeled to increase with the taphonomic grade. This process features both the loss and gain of characters with grade. The ability to code some characters with an increase in taphonomic alteration may be counterintuitive, but abrasion of plates allows the observation of internal structures (e.g., pores in diploporitans), and the removal of some features can permit the coding of others (e.g., the loss of crinoid arms allows the coding of the tegmen or peristomial surface).

The blastozoan and crinoid characters were then classified as observable or not for each taphonomic grade (Table 1) according to conservative taphonomic interpretation and field observations of various taphofacies (Supplemental Data 3, 4). In crinoids, all interpreted as Type 2 skeletons, characters that are unlikely to be observed were excluded from the analysis such that the size of the character suite decreased with taphonomic grade. Blastozoans required a slightly more elaborate procedure resulting from the inclusion of multiple different skeletal types (1-3). If a character was unobservable for all three skeletal types at a specific state of taphonomic degradation (taphonomic grade), then it was excluded from the analysis, as was done with the crinoid data set. However, if a character is likely to become unobservable at a certain taphonomic grade for one or more, but not all, of the skeletal types, then it was coded as missing and the character was retained.

The data sets were then analyzed using Gower's similarity coefficient (Gower, 1971). This similarity coefficient allows for the inclusion of missing data along with quantitatively differentiating between nonapplicable and missing or unknown data (Deline and Ausich, 2011). This metric is calculated as the number of shared character states between two taxa divided by the number of characters for which at least one of the two is applicable. The distribution of taxa in the taphonomically altered data sets can be compared to the original data set by calculating the Mantel statistic, which compares random permutations of the distance between individuals. The distribution of taxa can also be visualized using principal coordinate analysis (PCO). This analysis, along with Gower's similarity coefficient, can potentially create triangle inequalities within multidimensional space, which can be prevented by adding a small value to zero distances within the analysis (Cailliez, 1983). The changing of the character number and states for each taphonomic grade necessitates independent ordinations, which produce unique morphospaces with noncomparable absolute distances. Using ratios of distances such that they can be directly compared circumvented this issue. In particular, we used partial 

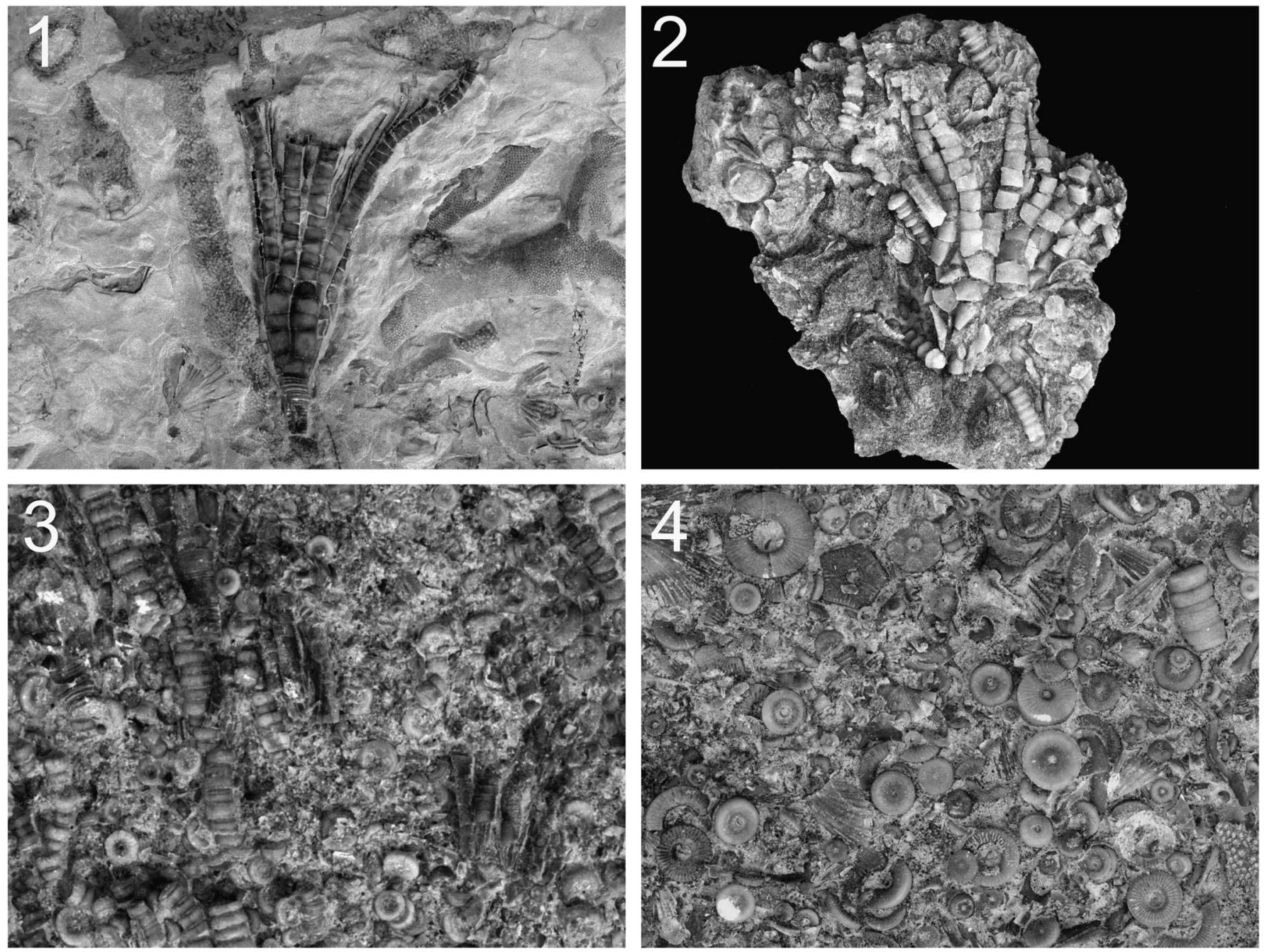

Figure 1. An example of taphonomic degradation in the Late Ordovician disparid crinoid (skeletal type 2) Ectenocrinus simplex Hall, 1847 from the Kope Formation of the type Cincinnatian. (1) Taphonomic Grade A, an intact specimen with arms and stem showing delicate features such as ramules (x 2.8). (2) Taphonomic Grade B, a disrupted cup with partial arms and limited proximal stem (x 2.6). (3) Taphonomic Grade C, partial crinoid modules including disrupted cups and segments of the arms and column (x 3.6). (4) Taphonomic Grade D, isolated ossicles attributed to E. simplex intermixed with other species of crinoid (x 3.1)

Table 1. Number of taxa, skeletal types, and number of characters identified as observable in the four taphonomic grades (A-D) of Brett et al. (1997) for the two data sets used in the current study. Data on crinoids from Ausich et al. (2015) and Deline and Ausich (2017); data on blastozoans from Foote (1992).

\begin{tabular}{lrrrr}
\hline & \multicolumn{2}{c}{ Crinoids } & \multicolumn{2}{c}{ Blastozoans } \\
\hline Skeletal type & 2 & 1 & 2 & 3 \\
Number of taxa & 163 & 7 & 83 & 41 \\
Number of characters & 145 & 56 & 56 & 56 \\
Grade A characters & 145 & 56 & 56 & 56 \\
Grade B characters & 124 & 31 & 52 & 50 \\
Grade C characters & 63 & 13 & 28 & 40 \\
Grade D characters & 15 & 13 & 14 & 25 \\
\hline
\end{tabular}

disparity (Foote, 1993), which is defined as the ratio of the disparity with a specific group excluded to the total disparity. Partial disparity at different taphonomic grades was calculated for taxonomic groups in crinoids (camerates, disparids, and cladids, including flexibles) and skeletal types for blastozoans (Types 1-3). Disparity is calculated as the average squared distance between taxa within morphospace. A partial disparity of 1.0 indicates that the removal of those taxa has no effect on the overall disparity. Values lower than 1 reflect that disparity decreases when those animals are removed; values higher than 1 indicate a disparity increase with the removal of a particular group.

The reduction of the characters or character states inherently alters the produced morphospace, distribution of characters, and perceived patterns of disparity. Therefore, the taphonomic loss of characters was compared with random loss of characters according to a resampling routine. For each taphonomic grade, 1,000 random samples were produced with equivalent character loss, or in the case of blastozoans, equivalent missing character states were added according to skeletal type. Mantel tests and partial disparity were then calculated for the random subsamples, and the median, fifth, and ninety-fifth percentiles were calculated and analyzed as a comparison between taphonomic and random character loss. All analyses were run using $\mathrm{R}$ version 3.0.3 (R Core Team, 2014). 


\section{Assessing temporal trends}

Potentially more important than assessing the extent of a bias is exploring how it might alter perceived trends. To explore this, we conducted two analyses at two different temporal scales: within a stratigraphic sequence and through geologic time.

Stratigraphic model.-A generalized stratigraphic sequence containing several distinct depositional environments was produced to simulate the effects of differential preservation on crinoid disparity. Four intervals within this theoretical sequence, representing settings characterized by dissimilar suites of paleoenvironmental processes and therefore capable of producing distinctive taphofacies (sensu Speyer and Brett, 1986), were selected as datums. Using the sequence stratigraphic terminology of Catuneanu (2006), these intervals comprise a carbonate interval within the transgressive systems tract, a siliciclastic mudstone interval within the early highstand systems tract, an impure mudstone interval within the late highstand systems tract, and a calcareous siltstone interval within the falling stage systems tract. All lithologic characteristics, sequence stratigraphic interpretations, and taphofacies descriptions strongly agree with direct field observations as well as published data (e.g., Brett, 1995; McLaughlin et al., 2008).

The carbonate environment represents deposition during a phase of relatively rapid base-level rise, resulting in siliciclastic sediment starvation in distal environments and a corresponding increase in the amount of time a skeleton would remain in the taphonomically active zone. Consequently, total disarticulation is assumed for all echinoderm skeletons. Characters related to isolated ossicles and features that would otherwise be concealed but are revealed through disarticulation control the disparity in this interval.

The siliciclastic mudstone-dominated intervals represent deposition following waning base-level rise followed by the transition into stillstand, which, in turn, transitions into gradual base-level fall, eventually progressing into increasingly rapid base-level fall. Hence, the transition between transgressive and early highstand systems tracts (i.e., the maximum flooding surface) is generally not a particularly prominent surface. During early highstand, the relatively slow rate of base-level fall resulted in generally low background sedimentation rates; in distal environments, sedimentation is dominated by siliciclastic clays. Given the slow background sedimentation rate, episodic rapid burial events become stacked in thin intervals where the primary mechanism for sediment accumulation is in the form of obrution events. Repeated rapid burial of crinoid populations by fine-grained sediment results in genesis of a taphofacies characterized by an abundance of completely articulated individuals; thus, complete skeletal articulation is assumed for the early highstand interval. By contrast, the comparatively elevated background sedimentation associated with increasing base-level fall produces a late highstand taphofacies where articulation is not as common. Although it may initially appear paradoxical that increased sedimentation rate would result in a decreased frequency of articulated crinoids, the overall sedimentation rate is only moderate compared to other phases of base-level change but is nevertheless sufficient to separate ('unstack') episodic rapid burial horizons, splaying apart obrution horizons with greater thicknesses of background sediment; hence, the general taphofacies is dominated by partially articulated or disarticulated specimens buried moderately quickly to somewhat slowly during background intervals. The fine grain size of these two taphofacies would preclude loss of surface features via abrasion, even in isolated ossicles.

The calcareous siltstone interval represents deposition during a relatively rapid phase of base-level fall. This resulted in significantly increased influx of coarser-grained siliciclastic sediment into distal settings and a shift to more energetic environments. As with the late highstand taphofacies described in the preceding, an increased rate of background sedimentation does not correlate with increased preservational quality as the higher energy settings are associated with elevated rates of abrasion on exposed skeletal material as well as frequent erosion and exhumation of crinoid carcasses even if initially buried relatively rapidly. Hence, total disarticulation is assumed for all crinoids, as is loss of surface details of isolated ossicles.

Stratigraphic and taphonomic assumptions. - Certain assumptions of the model used in this study require some justification from stratigraphic and taphonomic perspectives as any number of stratigraphic scenarios and taphonomic interpretations can be employed in order to test theoretical relationships. Specifically, the following are worth brief commentary: (1) the use of a mixed carbonate-siliciclastic sequence for our modeled stratigraphic setting, (2) the use of crinoids to the exclusion of other echinoderm groups in modeling disparity changes through a stratigraphic sequence, (3) the degree to which the modeled distribution of crinoids realistically reflects crinoid occurrences, (4) the use of the specific crinoid taxa selected for the model, and (5) the basis for interpreting which features are likely to be lost or retained within each analyzed portion of the theoretical stratigraphic sequence.

The stratigraphic model used to study disparity through changing depositional environments is based on a mixed carbonate-siliciclastic system in an epeiric setting. This was selected because the interplay between siliciclastic influx and carbonate production in the absence of siliciclastic influx results in strong contrasts in sediment character and paleoenvironmental processes between different, discrete phases of baselevel change. These relationships are more subtle, and therefore more difficult to model clearly, in pure siliciclastic and pure carbonate systems (e.g., Catuneanu, 2006). Moreover, a mixed carbonate-siliciclastic system is characteristic of the Ordovician through Devonian of the greater eastern midcontinent and northern Appalachian Basin of North America, a region where numerous high-resolution stratigraphic and paleontologic studies have produced an unparalleled database for echinoderm occurrences with regard to sequence stratigraphic setting (for details of eastern North American middle Paleozoic sequence stratigraphy see, e.g., Holland and Patzkowsky, 1996; Brett et al., 2004, 2012; McLaughlin et al., 2008; Ettensohn et al., 2013).

Crinoids were selected as an ideal group to test changes in disparity through a theoretical depositional sequence. Crinoid taxa were analyzed rather than other echinoderm groups because they represent Type 2 morphologies, making them 
potentially more sensitive than other echinoderms to taphonomically induced variability in observable characters. More important, crinoids (specifically the species included in the current study) are far more abundant and taxonomically diverse in Paleozoic mixed carbonate-siliciclastic systems than are taphonomically comparable blastozoans (Frest et al., 1999). Crinoids occur in an unmatched variety of lithofacies, allowing interpretation of paleoenvironmental controls on preservation at a level exceeding that which is currently possible for most blastozoans. In addition, blastozoans are generally abundant primarily in carbonate environments only (Brett et al., 1997; Frest et al., 1999).

The subsampled crinoid data set analyzed at each of the selected intervals of the stratigraphic sequence reflects changes in diversity observed in field studies. Given the generalized paleoenvironments analyzed (see the preceding), an equal number of crinoid taxa at each phase of base-level change is an unrealistic assumption. The transgressive systems tract was treated as the interval where crinoid diversity is greatest, owing to the low turbidity of water during sediment deposition, the increased availability of hard substrata (including abundant hardgrounds), and the strong stratigraphic condensation (i.e., 'time richness'). Fewer crinoid taxa were analyzed as part of the overlying early highstand systems tract, with even fewer representing the upper highstand systems tract. This reflects increasing sedimentation and soft, muddy substrates, which limits the number of crinoids to those capable of occupying such environments. The lowest crinoid diversity is interpreted for the falling stage systems tract, an interval that typically contains few crinoids, except in local lenses or patches (e.g., Frest et al., 1999). This most likely reflects the increases in sedimentation rate, siliciclastic influx, and grain size associated with the falling stage systems tract.

Although the diversity of crinoids analyzed at each selected phase of our model stratigraphic sequence changes in order to better reflect field data, the subsampled data set of specific crinoid taxa analyzed was the same for each of the stratigraphic intervals. That is, the same crinoid taxa were considered for each of the four phases of relative base-level change, but the number of taxa varied at each of the stratigraphic intervals described in the preceding. These taxa were chosen from the larger data set because they represent a range of crinoids that are relatively common in the Middle Ordovician-Early Silurian of eastern North America, resulting in a more realistic match between the lithofacies and taphofacies in the theoretical stratigraphic sequence and at least some of the crinoids encountered within them. Perhaps more important, selected crinoids represent taxa that are known from relatively complete specimens: this resulted in a larger and less initially taphonomically biased set of characters that could be coded (for example, properties of the distal arms and stem could not be coded for many taxa within the larger echinoderm data set due to rapid disarticulation from other skeletal modules identifiable to low taxonomic levels). Since close to the full morphology of these crinoids is known, these taxa are particularly well suited for accurately capturing disparity and determining the effects of taphonomy on this measure.

It is somewhat unrealistic to assume that the exact same crinoid taxa will be present in all of the depositional environments described in our theoretical stratigraphic sequence. For example, taxa that are particularly susceptible to fouling by fine-grained sediments and/or unable to occupy soft substrates will occur primarily or exclusively in carbonate hardground facies, which are best developed during major transgressive intervals in mixed carbonate-siliciclastic systems (e.g., Thomka and Brett, 2015). Conversely, those taxa that are particularly tolerant of turbidity and/or readily able to occupy soft, shifting, or unstable substrata may be restricted to various siliciclastic facies. Nevertheless, use of the same crinoid taxa to test disparity within all of the taphofacies of our stratigraphic sequence is important for this initial exploration of the effects of taphonomic processes on controlling crinoid disparity: if the same taxa are used in all taphofacies, then patterns in disparity should be more strongly developed than what is likely to be observed within any single real-world stratigraphic sequence. Hence, it is worthwhile to test whether any potentially valuable pattern is capable of being discerned at all, and this is best accomplished using the same set of morphologically welldescribed taxa as standards.

The rationale for determining which features are likely to be preserved within each taphofacies was largely described in the overview of each studied interval of the stratigraphic sequence. It is important to note that characters for comparing disparity among the selected taphofacies were assessed independently from previous analyses. This was done to account for taphofacies where certain crinoid taxa are likely to be preserved as a variety of skeletal modules regardless of whether they, as a whole, are considered Type 1, Type 2, or Type 3 echinoderms.

On the basis of the preceding rationale, we quantified local crinoid disparity through the idealized stratigraphic section. The original data set was culled to only include crinoids and characters that contained low levels of missing data (less than $10 \%)$. The resulting data set consisted of 153 characters describing 27 crinoids, all of which had preserved arms and distal attachment structures. These 27 crinoids were then split into two groups, one that would be modeled for taphonomic alteration through a stratigraphic section and an unaltered control group. Thirteen exclusively Ordovician taxa were used to represent a theoretical community that contained all of the major crinoid groups (camerates, disparids, cladids, as well as a flexible and a hybocrinid); this community was subjected to modeled taphonomic degradation corresponding to each taphofacies within the stratigraphic section. The other 14 taxa were left taphonomically unaltered as the control group. At each interval in the stratigraphic section, characters that are unlikely to be preserved were coded as missing for the taphonomically altered group, whereas all characters were coded as present for the control group at each stratigraphic datum. In addition, random subsets of crinoids were sampled (1,000 times) at some of the stratigraphic datum to assess how the morphological metrics change with a lower chance of recovering all of the taxa in an assemblage. The upper highstand systems tract datum, for example, is modeled as containing five out of the 13 taxa, so the metrics are based on 1,000 random subsets of five crinoids with the corresponding taphonomically reduced character suite. By contrast, this step was skipped for the transgressive systems tract datum in which all 13 crinoid taxa are modeled as likely to be 
recovered during sampling. The local disparity was then assessed by calculating a Mantel statistic between the taphonomically altered subset and their original distribution in morphospace as well as the partial disparity of the taphonomically altered crinoids compared to all 27 crinoids.

Paleozoic trends in blastozoans. - In addition to the small-scale temporal patterns observable within stratigraphic cycles, broader temporal trends in preservation could alter estimations of morphological diversity and prevent an accurate evolutionary assessment of clades. Secular changes in oceanic chemistry, tectonic setting, and/or evolutionary paleoecology could all alter the distribution of preservational processes through time. This is evident in the non-randomly distributed frequency of Lagerstätten through time, largely based on occurrence of soft-tissue preservation (Allison and Briggs, 1993; Schiffbauer and Laflamme, 2012). Articulated echinoderm remains require unique conditions not necessarily correlative with those of softtissue preservation, but a comparable study of Phanerozoicscale echinoderm-specific Lagerstätten has yet to be conducted (but see Hess et al., 1999 for a review for crinoids). Therefore, the frequency of soft-tissue Lagerstätten compiled by Schiffbauer and Laflamme (2012) was used as a first-pass proxy to test how varying preservation through the Phanerozoic may alter our perceptions of the overall disparity of a clade.

The Foote (1992) blastozoan data set was used to examine how temporal trends could alter perceptions of disparity through time. This data set is optimal because of its long temporal coverage compared with the AEToL crinoid data set; however, the shifting proportions of different echinoderm skeletal types $(1,2$, and 3$)$ through the Paleozoic provides an additional level of complexity. Although these biases are already contained within the original echinoderm data set to some degree, the preservational differences were amplified in an attempt to see whether a discernable bias exists. The frequencies of Lagerstätten were scaled with taphonomic grade according to the broad underlying assumption that geologic intervals that contain a large number of soft-tissue Lagerstätten would also be associated with high-fidelity preservation of blastozoans, whereas intervals that contain few soft-tissue Lagerstätten are assumed to be associated with more taphonomically altered blastozoans. For example, blastozoans that occur in geologic periods such as the Cambrian, with a large number of known Lagerstätten, were universally coded as if they were preserved in Taphonomic Grade A (as was done in earlier analyses). By contrast, blastozoans that occurred in intervals with few known marine Lagerstätten, such as the Silurian or Permian, were universally coded as if they were preserved in Taphonomic Grades C or D. Trends in disparity through time were then analyzed in both the original and the taphonomically altered data sets.

\section{Results}

The morphospaces produced by these two data sets have been previously discussed to some extent (Foote, 1992; Deline and Ausich, 2017), but their structures warrant a brief discussion (Figs. 2.5, 3.5). The blastozoan morphospace shows a gradation of morphologies with clusters of major taxonomic groups, but with little space differentiating those morphotypes. For example, the blastoids all group tightly together (gray diamonds), but the area they occupy overlaps with other blastozoans such as the diploporitans and eocrinoids. Major groups of crinoids are more prominently separated into distinctive areas of morphospace, which likely reflects the greater number of characters assessed for crinoids compared with the blastozoan data set. In addition, there are suites of characters that establish the major groups; for example, dozens of characters associated with fixed rays distinguish the camerates from the disparids and cladids. The different groups of crinoids occupy various amounts of morphospace; the disparids, in particular, occupy a large area, which is related to having two distinctive forms with the inclusion of the bilaterally symmetrical and recumbent calceocrinids.

Both of these data sets were systematically degraded as would be expected if those animals were only known from Taphonomic Grades A-D. Both in the distribution of taxa (Fig. 2.1) and the partial disparity of different morphotypes (Fig. 2.2-2.4), the taphonomically altered blastozoans showed little difference from what would be expected given random character loss. This is also the case with the distribution of taxa within the blastozoan morphospaces (Fig. 2.5-2.8); as the taphonomic grade increases, the included taxa become more dispersed and the detail contained within the ordination is lost, but the relative positions of the major morphologies and taxonomic groups are retained.

The crinoid data set shows a very different pattern from that of the blastozoans. Both the distribution of taxa as seen by the Mantel statistic (Fig. 3.1) and the partial disparity (Fig. 3.2-3.4) of the major taxonomic groups change dramatically with increased taphonomic grade and far beyond what is expected given random character loss. The change in partial disparity is also concerning given the different trajectories of the different taxonomic groups. For example, the removal of disparids from calculations of disparity is much more influential at higher taphonomic grade while the inverse is seen in camerates. As with the blastozoans, the trends seen in the disparity metrics are also apparent in the morphospaces (Fig. 3.5-3.8). The morphospaces produced at Taphonomic Grades B and C still retain the separation of the major taxonomic groups of crinoids, but there are shifts in position as well as introduction of individuals that appear intermediate in morphology between groups. At Taphonomic Grade D, in which only characters that can be

Figure 2. The effect of taphonomic degradation on morphological characterization of blastozoan echinoderms. (1) Mantel statistic comparing the distribution of taxa based on the Gower Dissimilarity Coefficient between the taphonomically altered and original blastozoan data sets. (2-4) Partial disparity, in black, of the three echinoderm skeletal types (Types 1-3 of Brett et al., 1997) as they are progressively degraded taphonomically. Disparity is calculated as the squared distance of taxa within morphospace. Partial disparity as defined by Foote (1992) is the disparity excluding the group in question divided by total disparity. To assess the change in metrics associated with generalized loss of information (reduction of included morphological characters), 1,000 randomized samples with added randomized missing characters and character states matching each taphonomic grade were analyzed and the median (gray line) as well as 5th and 95th percentiles (gray dashed lines) are reported. Error bars are calculated on the basis of the standard error of the resampled data. (5-8) Morphospaces showing the change in morphologic distribution with the loss of information from taphonomic alteration. Skeletal Type 1 blastozoans (some eocrinoids) are indicated by a plus; Skeletal Type 2 blastozoans (some eocrinoids, rhombiferans, diploporitans, and paracrinoids) are indicated by an open circle; Skeletal Type 3 blastozoans (coronoids and blastoids) are indicated by a gray diamond. 

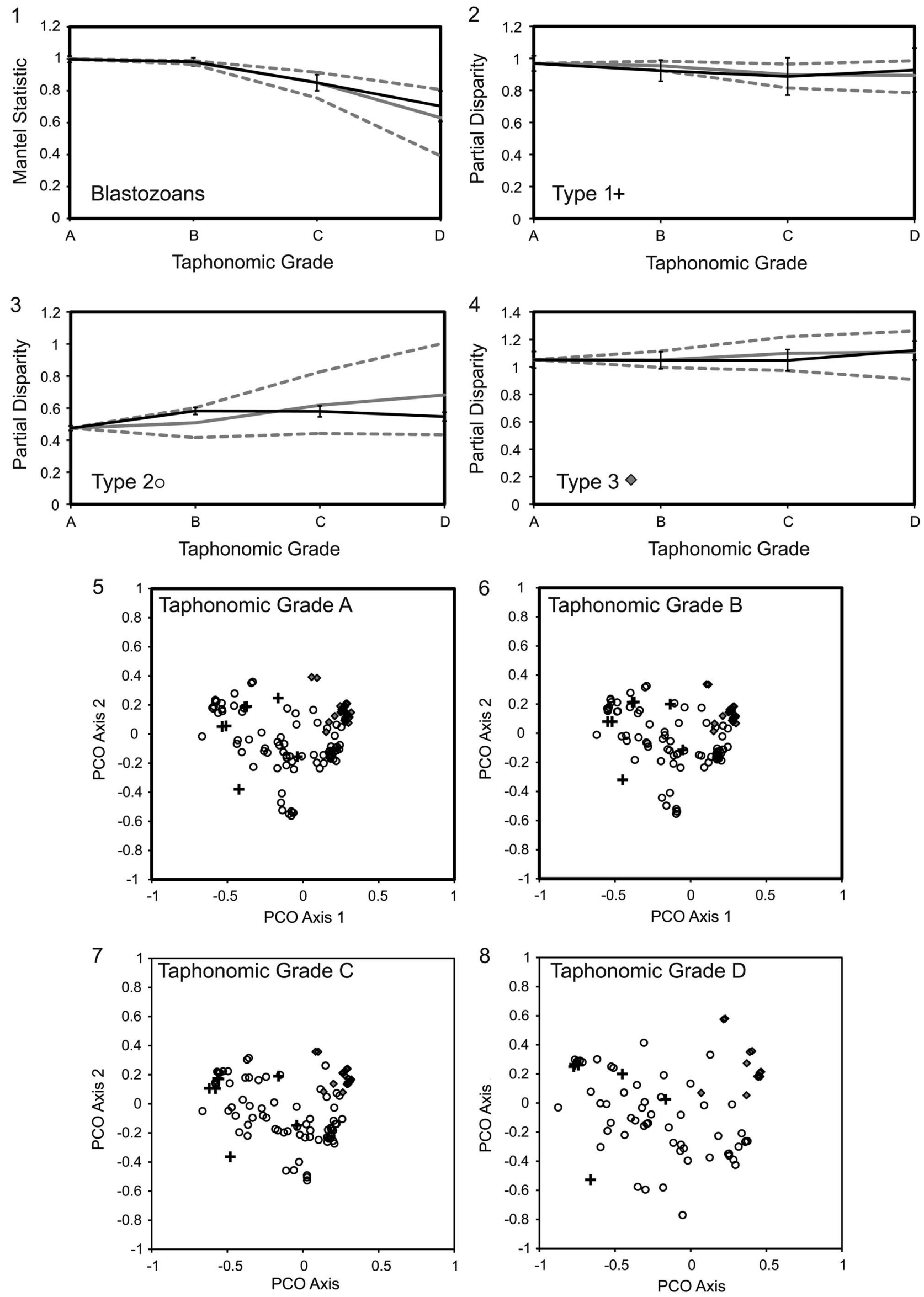
observed in isolated ossicles are coded, the morphospace becomes uninformative with all of the included groups overlapping in an indistinct cloud of points.

The perception of morphologic diversity contained within a crinoid assemblage through an idealized stratigraphic cycle is shown in Figure 4. The partial disparity of the altered taxa compared with the control assemblage (Fig. 4.4) and the relative distribution of taxa based on the Mantel statistic (Fig. 4.5) are relatively indistinguishable from the original data set through most of the section. However, the condensed assemblages found in the transgressive systems tract are noticeably different because of fewer observable characters even though all of the taxa within the assemblage are likely to be observed.

The effect of an exaggerated taphonomic bias in blastozoan morphologic diversity through the Paleozoic is presented in Figure 5. As was discussed by Foote (1992), blastozoans are characterized by a rapid rise in morphological disparity early in the group's history (Cambrian-Early Ordovician) followed by a contraction of morphology within groups. Coupled with the extinction of multiple blastozoan classes, this resulted in a steady and significant reduction in disparity from the Silurian to the Mississippian. The only blastozoans present during the Late Paleozoic were the morphologically conservative blastoids, such that disparity remained low. Exaggerating potential taphonomic biases based on the frequency of marine Lagerstätten had little effect on the disparity trends in blastozoans through the Paleozoic. The only difference can be seen during the Devonian, in which the taphonomic alteration makes the drop in disparity appear later and more gradual than in the original data set. This is largely the result of the loss of strong clustering within rhombiferans and blastoids and, more important, the outlier position of the morphologically distinctive blastoid Eleutherocrinus (Millendorf, 1979).

\section{Discussion}

The quantification of morphology in order to detect trends in morphological diversity through time is a vital approach in unraveling macroevolutionary processes. Examination of potential biases that influence disparity metrics is as important as studies of the patterns and rates of change in disparity through time. The largest potential bias is undoubtedly variation in preservation, which can alter biodiversity as well as nonrandomly distort observed morphological features. However, the role of taphonomy has been understudied such that it is unknown whether the prominent patterns in disparity (Hughes et al., 2013) are the result of evolutionary processes or, to some degree, an artifact of taphonomic alteration. Echinoderm taphonomy is well studied, which allows a system in which the potential effects of variable preservation can be exaggerated in order to explore the magnitude of this theoretical potential bias.
In addition, these simulated effects represent a 'best case scenario' of sorts for documenting which taphofacies are best for capturing echinoderm disparity, which taphofacies are most likely to produce no or spurious patterns, and which taphofacies are less than ideal but still capable of producing informative patterns.

Examination of the distribution of taxa within morphospace and the relative contribution of individual groups to overall disparity indicate the influence of taphonomy on morphological signals is very different for crinoids and blastozoans (Figs. 2, 3). This difference is important in stressing how the fossil record for even similar appearing and related groups can be quite distinctive and nonuniform. For blastozoans, the loss of taphonomically sensitive characters produces morphological patterns that are well within those produced by merely reducing the size of the character suite. In other words, the characters that are influencing the major axes and, therefore, are contributing to the differentiation between morphotypes are taphonomically resistant. The characteristics that define different taxonomic groups are largely defined by respiratory structures in addition to the size and type of thecal plates, all of which can potentially be recognized from isolated ossicles (e.g., Paul et al., 2016). The features within blastozoans that are rapidly lost following death, such as the distal stalk, anal pyramid, and feeding appendages, are fairly consistent across blastozoan morphotypes such that they contribute little to the overall disparity. This is not the case with crinoids, where the characters that define the morphological groups of crinoids are lost with increasing taphonomic degradation. The characters that are important in structuring morphospace primarily relate to the structure of the cup, anal series, fixed rays, and interareas, which all require the preservation of most, if not all, of the calyx. For example, an isolated basal plate does not necessarily help distinguish one crinoid subgroup from another, with the possible exception of morphologically aberrant forms such as the calceocrinids.

If patterns in disparity as they relate to taphonomy are examined through either an idealized stratigraphic section (for crinoids; Fig. 4) or through the Phanerozoic (for blastozoans; Fig. 5), results are encouraging. However, patterns of crinoid disparity through time might appear to be suspect given the results of Figure 3, but previous analyses conducted by Foote (1999) should alleviate those concerns. Foote (1999) found that disparity derived from exclusively cup characters, which could be easily discerned in Taphonomic Grades A-C, mimicked the overall disparity pattern. In addition, Foote (1999) noted that the pair-wise distance was not strongly influenced by missing data. Therefore, the current study aims to explore potential biases rather than correcting previous studies in an attempt to elucidate the true history of echinoderm disparity. Patterns of local disparity among crinoids are only significantly altered within the most taphonomically altered portions of the stratigraphic section (transgressive systems tract). This part of the sequence features

Figure 3. The effect of taphonomic degradation on morphological characterization of crinoids. (1) Mantel statistic comparing the distribution of taxa based on the Gower dissimilarity coefficient between the taphonomically altered and original crinoid data sets. (2-4) Partial disparity, in black, of the major groups of crinoids included in the data set (camerates, disparids, and cladids, including flexibles) as they are progressively degraded taphonomically. Error bars and the comparison to randomized character loss follow the methods described for Figure 2. (5-8) Morphospaces showing the change in morphologic distribution with the loss of information from taphonomic alteration. Cladids/flexibles are indicated by an open dash; camerates are indicated by an open circle; protocrinids are indicated by a plus; hybocrinids are indicated by a gray asterisk; disparids are indicated by a gray triangle. 

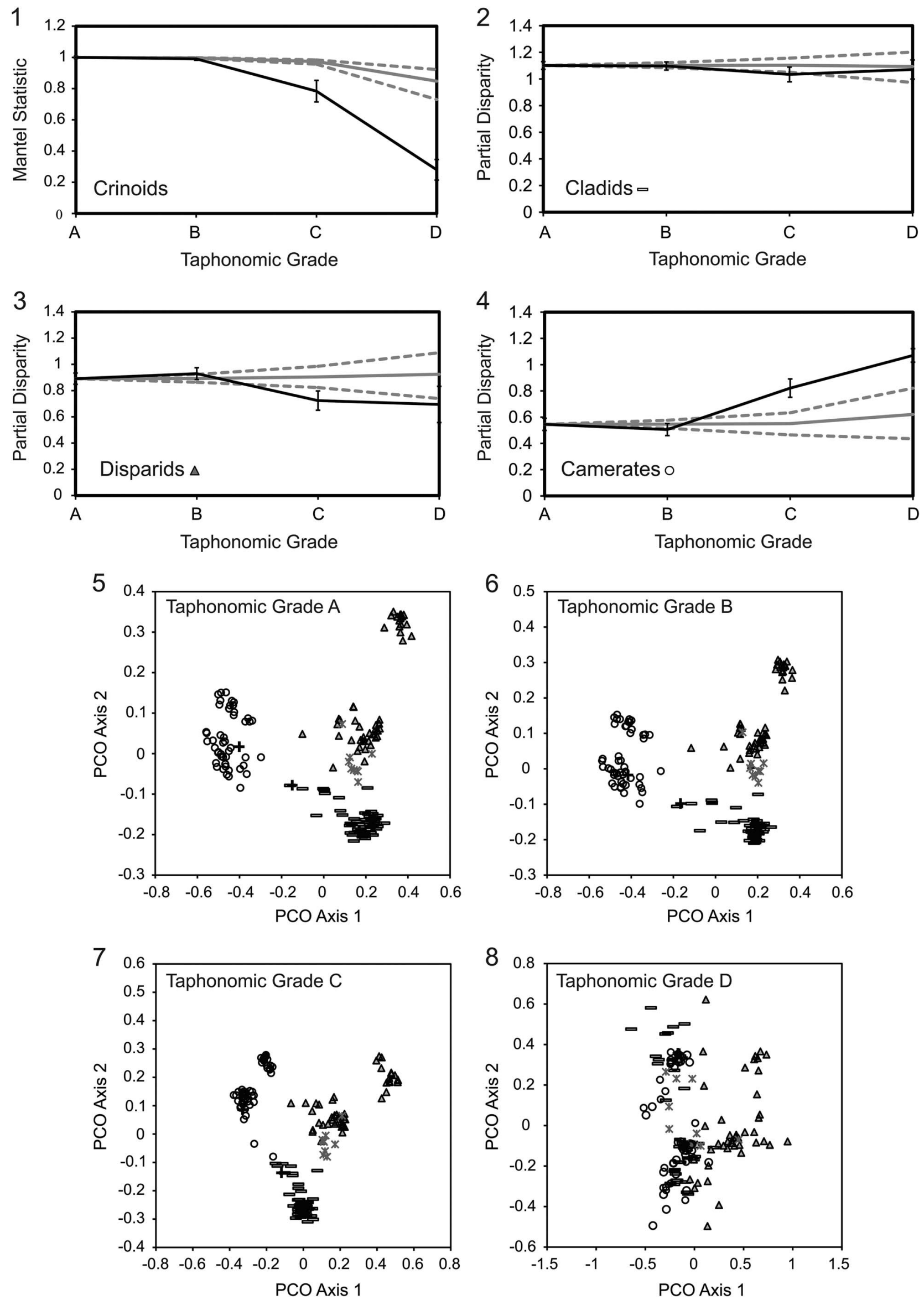



limestone mudstone carbonates siltstone

Figure 4. The effect of taphonomic alteration on local crinoid disparity through an idealized stratigraphic sequence. (1) Idealized third-order stratigraphic sequence in a mixed carbonate-siliciclastic system. Even though echinoderms can be preserved throughout the section, four representative datums (transgressive systems tract, early highstand systems tract, late highstand systems tract, falling stage systems tract) were used to illustrate potential changes. (2) Changes in the number of crinoid taxa used at each datum. Note the highest diversity in the transgressive systems tract and the lowest diversity in the falling stage systems tract. (3) Changes in the number of observable characters at each of the stratigraphic datums. (4-7) Changes in observable morphological changes throughout the idealized stratigraphic section. For each datum where all 13 crinoid taxa are unlikely to be recovered, the partial disparity and mantel statistic are based on 1,000 random subsamples of the number of altered crinoids. (4) Partial disparity of the taphonomically altered sample compared to the complete data set of 27 crinoids; the partial disparity of the unaltered data set is shown by the vertical gray line. (5) Mantel statistic comparing the 13 taphonomically altered crinoids to their original morphological distribution. (6) The distribution of the altered (black) and unaltered (gray) crinoids in morphospace for the upper highstand systems tract taphofacies. The morphospaces for the lower highstand systems tract and falling stage systems tract are not shown, but are virtually indiscernible from this morphospace. (7) The distribution of the altered (black) and unaltered (gray) crinoids in morphospace for the transgressive systems tract.

extremely low rates of sedimentation such that echinoderm carcasses remain exposed on the seafloor for prolonged periods, resulting in complete disarticulation. Several previous studies have successfully focused exclusively on disarticulated remains (e.g., Meyer et al., 2002; Hunter and Zonneveld, 2008; Thomka et al., 2012), but the assemblages described in such studies are unlikely to be prime candidates for inclusion in studies of local disparity. Distinctive crinoid faunas may be contained within these environments, and these should be factored into studies of alpha diversity, but their inclusion in studies of crinoid disparity would be problematic given the potential bias associated with such taphonomic alteration. In a similar manner, blastozoan disparity as modeled by considering 'expected' taphonomic grades through the Paleozoic showed very little change when the taphonomic bias was artificially exaggerated (Fig. 5). The only interval that was altered with a decrease in preservation potential was the Devonian, which made the contraction of disparity appear later and more gradual than it would otherwise. This change was the result of the aberrant and preservable features within a morphological outlier (Eleutherocrinus), which can be easily recognized by the large increase in error bars during that interval.
The current analyses suggest that the bias associated with taphonomic degradation could be potentially predicted given a detailed understanding of the anatomy and taphonomy of the group in question. The effect of taphonomy is more pronounced within particular taxonomic groups, and that should be a point of consideration during experimental design in the choice of either characters or metric(s) used to quantify morphology. In addition, if the bias is fairly limited, then the inclusion of genera or species from disparate taphofacies is worthwhile. For example, one of the most diverse Laurentian assemblages of Silurian crinoids is the Hopkinton Dolomite (Witzke and Strimple, 1981), which is characterized by preservation as internal molds (Frest et al., 1999); this is also typical of preservation in the Silurian of the British Isles (Donovan et al., 2008). Inclusion of these organisms can greatly increase the amount of missing data within an analysis resulting from the unlikely preservation of the arms; despite imperfect preservation, these taxa retain enough of the morphologically valuable characters to allow relatively confident placement within morphospace. Conversely, crinoids known exclusively from isolated ossicles in highly condensed transgressive deposits, such as the columnal morphospecies Floricolumnus in the widespread 'bead beds' of the lower 

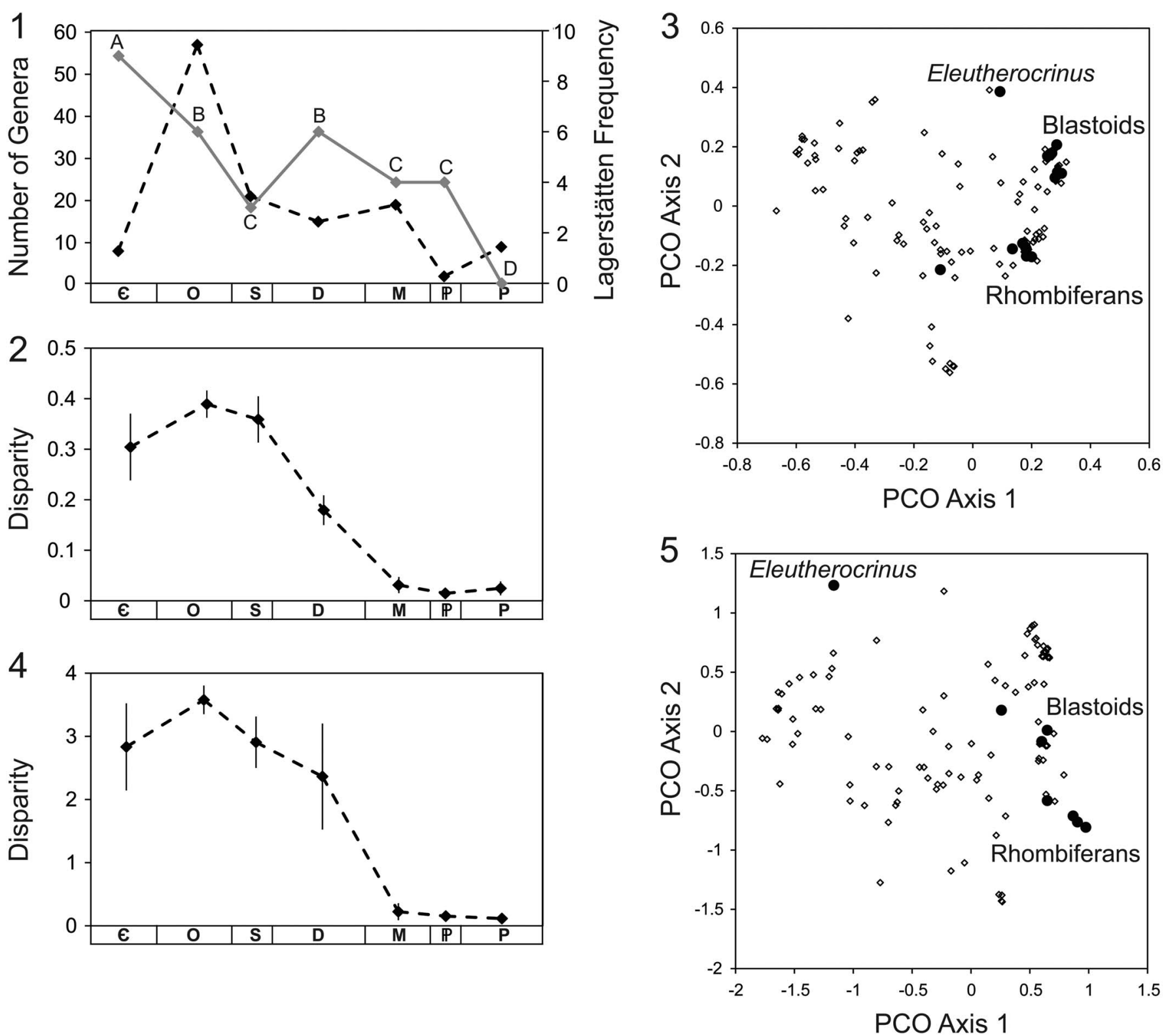

Figure 5. The effect of exaggerating taphonomic alteration on Paleozoic blastozoan disparity. (1) Sample size and the taphonomic proxy through time. The dashed line represents the number of blastozoan genera included in the analysis of temporal trends in disparity. The gray line represents frequency of soft tissue-bearing Lagerstätten through the Paleozoic (Schiffbauer and Laflamme, 2012); although this does not correspond directly to large-scale trends in echinoderm taphonomy, it is used as a proxy to examine how secular trends in taphonomy could potentially bias morphologic trends. This proxy is used to assign taphonomic grades (A-D) to the blastozoans within the data set. $(\mathbf{2}, \mathbf{3})$ Morphological disparity and morphospace of the unaltered blastozoan data set of Foote (1992). (4, 5) Morphological disparity and morphospace of the taphonomically exaggerated data set of Foote (1992). In both morphospaces, Devonian blastozoans are shown in black. Disparity is calculated as the average squared distance between taxa in morphospace, and error bars represent the standard error of bootstrap resampled data.

Silurian Brassfield Formation (Thomka et al., 2013), should be excluded from studies of morphological diversity or included with extreme caution. In a broader sense, estimations of sampling rates could be calculated for different body regions or taphonomic grades that would allow a better view of the taphonomic effects on morphology through time.

The results of this study provide a general guide for determining which taxa are appropriate to include in certain morphological studies and a framework for testing how taphonomic processes could bias studies of disparity within Echinodermata and potentially other taxonomic groups.

\section{Accessibility of supplemental data}

Data available from the Dryad Digital Repository: http://dx.doi. org/10.5061/dryad.m5t20

\section{Acknowledgments}

This project was funded by Assembling the Echinoderm Tree of Life Research Opportunity Award Supplements to National Science Foundation Grants 1036416 (W. Ausich) and 1036356 
(T. Kammer). University of West Georgia students G. Kinison, T. Fanning, and E. Young assisted in coding crinoid specimens and were funded by the UWG Student Research Assistance Program (SRAP). The AEToL character suite was constructed with W. Ausich and improved by helpful input from and discussions with T. Kammer and S. Donovan. We thank the following for providing access to curated specimens: T. Adrian, University of Iowa; R. Burkhalter, Sam Nobel Oklahoma Museum of National History; S. Butts and J. Utrup, Yale Peabody Museum of Natural History; J. Cundiff, Harvard University Museum of Comparative Zoology; K. Hollis, U.S. National Museum of Natural History; B. Hunda, Cincinnati Museum Center. The ideas in this study were greatly improved by discussions with W. Ausich, C. Brett, and M. Hopkins. Constructive reviews by M. Foote, P. Wagner, and D. Wright greatly improved this study.

\section{References}

Allison, P.A., 1990, Variation in rates of decay and disarticulation of Echinodermata: Implications for the application of actualistic data: Palaios, v. 5, p. $432-440$.

Allison, P.A., and Briggs, D.E.G., 1993, Exceptional fossil record: Distribution of soft-tissue preservation through the Phanerozoic: Geology, v. 21, p. $527-530$.

Ausich, W.I., 1997, Regional encrinites: A vanished lithofacies, in Brett, C.E., and Baird, G.C., eds., Paleontological Events: Stratigraphic, Ecological, and Evolutionary Implications: New York, Columbia University Press, p. 509-519.

Ausich, W.I., 2001, Echinoderm taphonomy, in Jangoux, M., and Lawrence, J.M., eds., Echinoderm Studies, Volume 6: Rotterdam, A. A. Balkema, p. 171-227.

Ausich, W.I., and Baumiller, T.K., 1993, Taphonomic method for determining muscular articulations in fossil crinoids: Palaios, v. 8, p. 477-484.

Ausich, W.I., and Baumiller, T.K., 1998, Disarticulation patterns in Ordovician crinoids: Implications for the evolutionary history of connective tissue in the Crinoidea: Lethaia, v. 31, p. 113-123.

Ausich, W.I., Kammer, T.W., Rhenberg, E.C., and Wright, D.F., 2015, Early phylogeny of crinoids within the pelmatozoan clade: Palaeontology, v. 58, p. 937-952.

Baumiller, T.K., 2003, Experimental and biostratinomic disarticulation of crinoids: Taphonomic implications, in Féral, J.P., and David, B., eds., Echinoderm Research 2001: Lisse, The Netherlands, Sweits and Zeitlinger, p. $243-248$.

Baumiller, T.K., and Hagdorn, H., 1995, Taphonomy as a guide to functional morphology of Holocrinus, the first post-Paleozoic crinoid: Lethaia, v. 28 p. 221-228.

Baumiller, T.K., Llewellyn, G., Messing, C.G., and Ausich, W.I., 1995, Taphonomy of isocrinid stalks: Influence of decay and autotomy: Palaios, v. 10 , p. $87-95$.

Blyth Cain, J.D., 1968, Aspects of the depositional environment and palaeoecology of crinoidal limestones: Scottish Journal of Geology, v. 4, p. 191-208.

Brett, C.E., 1995, Sequence stratigraphy, biostratigraphy, and taphonomy in shallow marine environments: Palaios, v. 10, p. 597-616.

Brett, C.E., and Baird, G.C., 1986, Comparative taphonomy: A key to paleoenvironmental interpretation based on fossil preservation: Palaios, v. 1 , p. 207-227.

Brett, C.E., and Baird, G.C., 1993, Taphonomic approaches to temporal resolution in stratigraphy: Examples from Paleozoic marine mudrocks, in Kidwell, S.M., and Behrensmeyer, A.K., eds., Taphonomic Approaches to Time Resolution in Fossil Assemblages: Paleontological Society Short Courses in Paleontology 6, Knoxville, Tennessee, Paleontological Society, p. 250-274.

Brett, C.E., Moffat, H.A., and Taylor, W.L., 1997, Echinoderm taphonomy, taphofacies, and Lagerstätten, in Waters, J.A., and Maples, C.G., eds. Geobiology of Echinoderms: Paleontology Special Papers 3, p. 147-190.

Brett, C.E., McLaughlin, P.I., Cornell, S.R., and Baird, G.C., 2004, Comparative sequence stratigraphy of two classic Upper Ordovician successions, Trenton Shelf (New York-Ontario) and Lexington Platform (Kentucky-Ohio) Implications for eustasy and local tectonism in eastern Laurentia: Palaeogeography, Palaeoclimatology, Palaeoecology, v. 210, p. 295-329.
Brett, C.E., Cramer, B.D., McLaughlin, P.I., Kleffner, M.A., Showers, W.J., and Thomka, J.R., 2012, Revised Telychian-Sheinwoodian (Silurian) stratigraphy of the Laurentian mid-continent: Building uniform nomenclature along the Cincinnati Arch: Bulletin of Geosciences, v. 87, p. 733-753.

Briggs, D.E.G., Fortey, R.A., and Wills, M.A., 1992, Morphological disparity in the Cambrian: Science, v. 256, p. 1670-1673.

Butler, R.J., Brusatte, S.L., Andres, B., and Benson, R.B.J., 2012, How do geological sampling biases affect studies of morphological evolution in deep time? A case study of pterosaur (Reptilia: Archosauria) disparity: Evolution, v. 66, p. 147-162.

Cailliez, F., 1983, The analytical solution of the additive constant problem: Psychometrika, v. 48, p. 343-349.

Catuneanu, O., 2006, Principles of Sequence Stratigraphy: Amsterdam, Elsevier, $376 \mathrm{p}$.

Ciampaglio, C.N., 2004, Measuring changes in articulate brachiopod morphology before and after the Permian mass extinction event: Do developmental constraints limit morphological innovation?: Evolution and Development, v. 6 , p. 260-274.

Ciampaglio, C.N., Kemp, M., and McShea, D.W., 2001, Detecting changes in morphospace occupation patterns in the fossil record: Characterization and analysis of measures of disparity: Paleobiology, v. 27, p. 695-715.

Crampton, J.S., 2007, Elliptic Fourier shape analysis of fossil bivalves: Some practical considerations: Lethaia, v. 28, p. 179-186.

Crônier, C., Renaud, S., Feist, R., and Auffray, J., 1998, Ontogeny of Trimerocephalus lelievrei (Trilobita, Phacopida), a representative of the Late Devonian phacopine paedomorphocline: A morphometric approach: Paleobiology, v. 24, p. 359-370.

Deline, B., 2009, The effects of rarity and abundance distributions on measurements of local morphological disparity: Paleobiology, v. 35, p. $175-189$.

Deline, B., 2015, Quantifying morphological diversity in early Palaeozoic echinoderms, in Zamora, S., and Rábano, I., eds., Progress in Echinoderm Palaeobiology: Cuadernos del Museo Geominero, v. 19, p. 45-48.

Deline, B., and Ausich, W.I., 2011, Testing the plateau: A reexamination of disparity and morphologic constraints in early Paleozoic crinoids: Paleobiology, v. 37, p. 214-236.

Deline, B., and Ausich, W.I., 2017, Character selection and the quantification of morphological disparity: Paleobiology, v. 43, p. 68-84.

Deline, B., Ausich, W.I., and Brett, C.E., 2012, Comparing taxonomic and geographic scales in the morphologic disparity of Ordovician through early Silurian Laurentian crinoids: Paleobiology, v. 38, p. 538-553.

Donovan, S.K., 1991, The taphonomy of echinoderms: Calcareous multielement skeletons in the marine environment, in Donovan, S.K., ed., The Processes of Fossilization: New York, Columbia University Press, p. 241-269.

Donovan, S.K., 2001, Evolution of Caribbean echinoderms during the Cenozoic: Moving towards a complete picture using all of the fossils: Palaeogeography, Palaeoclimatology, Palaeoecology, v. 166, p. 177-192.

Donovan, S.K., Lewis, D.N., Widdison, R.E., and Fearnhead, F.E., 2008, Ever since Ramsbottom: Silurian crinoids of the British Isles since 1954, in Ausich ,W.I., and Webster, G.D., eds., Echinoderm Paleobiology: Bloomington, Indiana University Press, p. 330-345.

Dornbos, S.Q., and Bottjer, D.J., 2001, Taphonomy and environmental distribution of helicoplacoid echinoderms: Palaios, v. 16, p. 197-204

Eble, G.J., 2000, Contrasting evolutionary flexibility in sister groups: Disparity and diversity in Mesozoic atelostomate echinoids: Paleobiology, v. 26, p. 56-79.

Erwin, D.H., 2007, Disparity: Morphological pattern and developmental context: Palaeontology, v. 50, p. 57-73.

Ettensohn, F.R., Lierman, R.T., Mason, C.E., Andrews, W.M., Hendricks, R.T., Phelps, D.J., and Gordon, L.A., 2013, The Silurian of central Kentucky, U.S.A.: Stratigraphy, palaeoenvironments and palaeoecology: Association of Australasian Palaeontologists Memoirs, v. 44, p. 158-189.

Foote, M., 1992, Paleozoic record of morphological diversity in blastozoan echinoderms: Proceedings of the National Academy of Sciences, v. 89, p. 7325-7329.

Foote, M., 1993, Contributions of individual taxa to overall morphological disparity: Paleobiology, v. 19, p. 403-419.

Foote, M., 1994, Morphological disparity in Ordovician-Devonian crinoids and the early saturation of morphological space: Paleobiology, v. 20, p. $320-344$.

Foote, M., 1997a, The evolution of morphological diversity: Annual Review of Ecology and Systematics, v. 28, p. 129-152.

Foote, M., 1997b, Sampling, taxonomic description, and our evolving knowledge of morphological diversity: Paleobiology, v. 23, p. 181-206.

Foote, M., 1999, Morphological diversity in the evolutionary radiation of Paleozoic and post-Paleozoic crinoids: Paleobiology, v. 25, supplement, $115 \mathrm{p}$. 
Frest, T.J., Brett, C.E., and Witzke, B.J., 1999, Caradocian to Gedinnian echinoderm associations of central and eastern North America, in Boucot, A.J., and Lawson, J.D., eds., Paleocommunities: A Case Study from the Silurian and Lower Devonian: Cambridge, Cambridge University Press, p. 638-783.

Gorscak, E., and O'Connor, P. M., 2016, Time-calibrated models support congruency between Cretaceous continental rifting and titanosaurian evolutionary history: Biology Letters, v. 12, 20151047.

Gorzelak, P., and Salamon, M.A., 2013, Experimental tumbling of echinoderms - Taphonomic patterns and implications: Palaeogeography, Palaeogeography, Palaeoecology, v. 386, p. 569-574.

Goswami, A., Milne, N., and Wroe, S., 2011, Biting through constraints: Cranial morphology, disparity and convergence across living and fossil carnivorous mammals: Proceedings of the Royal Society B, v. 278, p. 1831-1839.

Gower, J.C., 1971, A general coefficient of similarity and some of its properties: Biometrics, v. 27, p. 857-874.

Greenstein, B.J., 1991, An integrated study of echinoid taphonomy: Predictions for the fossil record of four echinoid families: Palaios, v. 6, p. 519-540.

Greenstein, B.J., 1992, Taphonomic bias and the evolutionary history of the family Cidaridae (Echinodermata: Echinoidea): Paleobiology, v. 18, p. $50-79$.

Greenstein, B.J., 1993, Is the fossil record of regular echinoids really so poor? A comparison of living and subfossil assemblages: Palaios, v. 8, p. 587-601.

Greenstein, B.J., Pandolfi, J.M., and Moran, P.J., 1995, Taphonomy of crownof-thorns starfish: Implications for recognizing ancient population outbreaks: Coral Reefs, v. 14, p. 91-97.

Guensburg, T.E., and Sprinkle, J., 2003, The oldest known crinoids (Early Ordovician, Utah) and a new crinoid plate homology system: Bulletin of American Paleontology, v. 364, 43 p.

Hall, J., 1847, Palaeontology of New York, Volume 1, Containing Descriptions of the Organic Remains of the Lower Division of the New-York System (Equivalent of the Lower Silurian Rocks of Europe). Natural History of New York, Part 6: New York, D. Appleton \& Company and Wiley \& Putnam; Boston, Gould, Kendall, \& Lincoln; Albany, Charles van Benthuysen, $338 \mathrm{p}$.

Hess, H., Ausich, W.I., Brett, C.E., and Simms, M.J., 1999, Fossil Crinoids: Cambridge, Cambridge University Press, 296 p.

Hetherington, A.J., Sherratt, E., Ruta, M., Wilkinson, M., Deline, B., and Donoghue, P.C.J., 2015, Do cladistics and morphometric data capture common patterns of morphological disparity?: Palaeontology, v. 58, p. 393-399.

Holland, S.M., and Patzkowsky, M.E., 1996, Sequence stratigraphy and longterm lithologic change in the Middle and Upper Ordovician of the eastern United States, in Witzke, B.J., Ludvigsen, G.A., and Day, J.E., eds., Paleozoic Sequence Stratigraphy: Views from the North American Craton: Geological Society of America Special Paper 306, p. 117-130.

Hopkins, M.J., 2014, The environmental structure of trilobite morphological disparity: Paleobiology, v. 40, p. 352-373.

Hughes, M., Gerber, S., and Wills, M.A., 2013, Clades reach highest morphological disparity early in their evolution: Proceedings of the National Academy of Sciences, v. 110, p. 13875-13879.

Hunter, A.W., and Zonneveld, J.-P., 2008, Palaeoecology of Jurassic encrinites: Reconstructing crinoid communities from the Western Interior Seaway of North America: Palaeogeography, Palaeoclimatology, Palaeoecology, v. 263 , p. $58-70$.

Kammer, T.W., Sumrall, C.D., Zamora, S., Ausich, W.I., and Deline, B., 2013, Oral region homology in Paleozoic crinoids and other plesiomorphic pentaradial echinoderms: PLoS ONE, v. 8, 16 p.

Kidwell, S.M., and Baumiller, T.K., 1990, Experimental disintegration of regular echinoids: Roles of temperature, oxygen, and decay thresholds: Paleobiology, v. 16, p. 247-271.

Kier, P.M., 1977, The poor fossil record of the regular echinoid: Paleobiology, v. 3, p. $168-174$.

Knauss, M.J., and Yacobucci, M.M., 2014, Geographic information systems technology as a morphometric tool for quantifying morphological variation in an ammonoid clade: Palaeontologia Electronica, v. 17, Art. 1.19, 27 p.

Lefebvre, B., Sumrall, C.D., Shroat-Lewis, R.A., Reich, M., Webster, G.D., Hunter, A.W., Nardin, E., Rozhnov, S.V., Guensburg, T.E., Touzeau, A., Noailles, F., and Sprinkle, J., 2013, Palaeobiogeography of Ordovician echinoderms, in Harper, D.A.T., and Servais, T., eds., Early Palaeozoic Biogeography and Palaeogeography: Geological Society of London Memoir, v. 38, p. 173-198.

Lewis, R.D., 1986, Relative rates of skeletal disarticulation in modern ophiuroids and Paleozoic crinoids: Geological Society of America Abstracts with Programs, v. 18, p. 672.

Liddell, W.D., 1975, Recent crinoid biostratinomy: Geological Society of America Abstracts with Programs, v. 7, p. 1169.

Lloyd, G.T., 2016, Estimating morphological diversity and tempo with discrete character-taxon matrices: Implementation, challenges, progress, and future directions: Biological Journal of the Linnean Society, v. 118, p. 131-151.
Lowenstam, H.A., 1957, Niagaran reefs in the Great Lakes area, in Ladd, H.S. ed., Treatise on Marine Ecology and Paleoecology: Geological Society of America Memoir 67, p. 215-248.

Macurda, D.B., and Meyer, D.L., 1983, Sealilies and feather stars: American Scientist, v. 71, p. 354-365.

Maples, C.G., and Archer, A.W., 1989, Paleoecological and sedimentological significance of bioturbated crinoid calyxes: Palaios, v. 4, p. 379-383.

Martin, E., Lefebvre, B., and Vaucher, R., 2015, Taphonomy of a stylophorandominated assemblage in the Lower Ordovician of Zagora area (central Anti-Atlas, Morocco), in Zamora, S., and Rábano, I., eds., Progress in Echinoderm Palaeobiology: Cuadernos del Museo Geominero, v. 19, p. $95-100$.

McLaughlin, P.I., Cramer, B.D., Brett, C.E., and Kleffner, M.A., 2008, Silurian high-resolution stratigraphy on the Cincinnati Arch: Progress on recalibrating the layer-cake, in Maria, A.H., and Counts, R.C., eds., From the Cincinnati Arch to the Illinois Basin: Geological Field Excursions along the Ohio River Valley: Geological Society of America Field Guide, v. 12, p. $119-180$

Meyer, D.L., 1971, Post-mortem disarticulation of Recent crinoids and ophiuroids under natural conditions: Geological Society of America Abstracts with Programs, v. 3, p. 645.

Meyer, D.L., 1990, Comparative taphonomy and population paleoecology of two edrioasteroid (Echinodermata) pavements: Upper Ordovician of Kentucky and Ohio: Historical Biology, v. 4, p. 155-178.

Meyer, D.L., and Meyer, K.B., 1986, Biostratinomy of Recent crinoids (Echinodermata) at Lizard Island, Great Barrier Reef, Australia: Palaios, v. 1, p. 294-302.

Meyer, D.L., Miller, A.I., Holland, S.M., and Dattilo, B.F., 2002, Crinoid distribution and feeding morphology through a depositional sequence: Kope and Fairivew formations, Upper Ordovician, Cincinnati Arch region: Journal of Paleontology, v. 76, p. 725-732.

Millendorf, S.A., 1979, The functional morphology and life habits of the Devonian blastoid Eleutherocrinus cassedayi Shumard and Yandel: Journal of Paleontology, v. 53, p. 553-561.

Nebelsick, J.H., Schmid, B., and Stachowitsch, M., 1997, The encrustation of fossil and recent sea-urchin tests: Ecological and taphonomic significance: Lethaia, v. 30, p. 271-284.

Paul, C.R.C., Donovan, S.K., Muir, L.A., Botting, J.P., Lin, J.-P., and Zhang, Y., 2016, Primitive Ordovician (Floian) echinoderms for Sandu, Guizhou Province, South China, and their significance: Geological Journal, v. 51, p. 143-156.

Pawson, D.L., 2007, Phylum Echinodermata: Zootaxa, v. 1668, p. 749-764.

R Core Team, 2014, R: A Language and Environment for Statistical Computing: Vienna, R Foundation for Statistical Computing.

Sansom, R.S., and Wills, M.A., 2013, Fossilization causes organisms to appear erroneously primitive by distorting evolutionary trees: Scientific Reports, v. 3 , Art. 2545,5 p.

Schiffbauer, J.D., and Laflamme, M., 2012, Lagerstätten through time: A collection of exceptional preservational pathways from the terminal Neoproterozoic through today: Palaios, v. 27, p. 275-278.

Shäfer, W., 1972, Ecology and Palaeoecology of Marine Environments: Chicago, University of Chicago Press, $568 \mathrm{p}$.

Sheffield, S.L., Zachos, L.G., and Lewis, R.D., 2012, A morphometric study of Erisocrinus (Crinoidea) using ArcGIS: Geological Society of America Abstracts with Programs, v. 44, p. 232.

Smith, A.B., 1984, Echinoid Palaeobiology: London, Allen and Unwin, 190 p. Speyer, S.E., and Brett, C.E., 1986, Trilobite taphonomy and Middle Devonian taphofacies: Palaios, v. 1, p. 312-327.

Speyer, S.E., and Brett, C.E., 1991, Taphofacies controls: Background and episodic processes in fossil assemblage preservation, in Allison, P.A., and Briggs, D.E.G., eds., Taphonomy: Releasing the Data Locked in the Fossil Record: New York, Plenum Press, p. 502-541.

Sumrall, C.D., 2000, The biological implications of an edrioasteroid attached to a pleurocystitid rhombiferan: Journal of Paleontology, v. 74, p. $67-71$.

Sumrall, C.D., and Waters, J.A., 2012, Universal Element Homology in glyptocystitoids, hemicosmitoids, coronoids, and blastoids: Steps toward echinoderm phylogenetic reconstruction in derived Blastozoa: Journal of Paleontology, v. 86, p. 956-972.

Thomka, J.R., and Brett, C.E., 2015, Paleoecology of pelmatozoan attachment structures from a hardground surface in the middle Silurian Massie Formation, southeastern Indiana: Palaeogeography, Palaeoclimatology, Palaeoecology, v. 420, p. 1-12.

Thomka, J.R., Mosher, D., Lewis, R.D., and Pabian, R.K., 2012, The utility of isolated crinoid ossicles and fragmentary crinoid remains in taphonomic and paleoenvironmental analysis: An example from the Upper Pennsylvanian of Oklahoma, United States: Palaios, v. 27, p. 465-480.

Thomka, J.R., Brett, C.E., and Simpkins, B.M., 2013, Anatomy of an epibole: Microstratigraphy of the 'bead bed' interval in the lower Silurian Brassfield 
Formation of central Kentucky: Proceedings of the 3rd International Geoscience Programme Project 591 Annual Meeting, p. 316.

Thomka, J.R., Brett, C.E., Bantel, T.E., Young, A.L., and Bissett, D.L., 2016 Taphonomy of 'cystoids' (Echinodermata: Diploporita) from the Napoleon quarry of southeastern Indiana, USA: The lower Silurian Massie Formation as an atypical Lagerstätte: Palaeogeography, Palaeoclimatology, Palaeoecology, v. 443, p. 263-277.

Villier, L., and Eble, G.J., 2004, Assessing the robustness of disparity estimates: The impacts of morphologic scheme, temporal scale, and taxonomic level in spatangoid echinoids: Paleobiology, v. 30, p. 652-665.

Wagner, P.J., 1997, Patterns of morphological diversification among the Rostroconchia: Paleobiology, v. 23, p. 115-150.

Webber, A.J., and Hunda, B.R., 2007, Quantitatively comparing morphological trends to environment in the fossil record (Cincinnatian Series; Upper Ordovician): Evolution, v. 61, p. 1455-1465.

Webster, M., and Hughes, N.C., 1999, Compaction-related deformation in Cambrian olenelloid trilobites and its implications for fossil morphometry: Journal of Paleontology, v. 73, p. 355-371.

Wills, M.A., 1998, Cambrian and Recent disparity: The picture from priapulids: Paleobiology, v. 24, p. 177-199.
Wilson, G.P., Evans, A.R., Corfe, I.J., Smits, P.D., Fortelius, M., and Jernvall, J., 2012, Adaptive radiation of multituberculate mammals before the extinction of dinosaurs: Nature, v. 483, p. 457-460.

Witzke, B.J., and Strimple, H.L., 1981, Early Silurian camerate crinoids of eastern Iowa: Proceedings of the Iowa Academy of Sciences, v. 88, p. 101-137.

Zamora, S., Lefebvre, B., Álvaro, J.J., Clausen, S., Elicki, O., Fatka, O., Jell, P., Kouchinsky, A., Lin, J.-P., Nardin, E., Parsley, R., Rozhnov, S. Sprinkle, J., Sumrall, C.D., Vizcaïno, D., and Smith, A.B., 2013a, Cambrian echinoderm diversity and palaeobiogeography, in Harper, D.A.T., and Servais, T., eds., Early Palaeozoic Biogeography and Palaeogeography: Geological Society of London Memoir, v. 38, p. 157-171.

Zamora, S., Darroch, S., and Rahman, I., 2013b, Taphonomy and ontogeny of early pelmatozoan echinoderms: A case study of a mass-mortality assemblage of Gogia from the Cambrian of North America: Palaeogeography, Palaeoclimatology, Palaeoecology, v. 377, p. 62-72.

Accepted 2 August 2016 